\title{
Challenges Besetting Teachers in the Implementation of E-Learning in Schools: A Guide to Curriculum Development
}

\author{
Mutendwahothe Walter Lumadi \\ Department of Curriculum and Instructional Studies, College of Education, \\ University of South Africa, South Africa \\ Lumadmw@unisa.ac.za
}

\section{Doi:10.5901/mjss.2014.v5n20p2814}

\section{Abstract}

This study was planned to examine potential challenges faced by teachers in the implementation of e-Learning in professional schools. The increasing desire to implement e-Learning programs and the incessant penetration of Information and Communication Technologies in the education sector motivated the researchers to carry out this study. Nevertheless, eLearning is multi-dimensional and involve the use of new Information and Communication Technologies to learn. Consequently, strategies designed to address problems in this kind of education must consider the challenges faced by teachers in its implementation. A survey of 796 student-teachers drawn from eight primary government teacher training colleges and three higher teacher training colleges in Cameroon was carried out. Data were collected using a questionnaire that was carefully designed with respect to the indicators of the study. Results revealed that slow Internet lines or access speed constitute a serious challenge to effective e-Learning in Cameroon. The problem of slow Internet lines was compounded by Inadequate Information and Communication Infrastructure; insufficient knowledge about e-Learning; recurrent power failure; lack of ICT based curriculum development programmes amongst others. The study also shows that e-Learning harbours many advantages for institutions of learning and individual students. However, to meet the challenges of ICTs, institutions of learning must work in partnership with telecommunication companies, national and international organisations to integrate ICTs in education. Teachers and students need to develop the ability to make proper use of modern technology by effectively integrating it into the teaching-learning process.

Keywords: e-Learning, Information Communication Technologies, Curriculum development, socio cultural approach, sampling, questionnaire, Cameroon

\section{Introduction}

Within the past two decades, professional schools and Universities in developing countries have been confronted with significant changes in their external and internal environments. They are forced to respond to emerging challenges and global trends in education such as continual developments and penetration of information and communication technologies (ICTs) in education. According to Lord Geoffrey Crowther at the inaugural ceremony of the UK Open University, 1969 cited in C.O.L (2006:11),

"the world is caught in a communication revolution, the effects of which will go beyond those of the industrial revolution of two centuries ago. Then the great advance was the invention of machines to multiply potency of Men's muscles. Now the great advance is the invention of machines to multiply the potency of Men's minds. As the steam engine was to the first revolution, so the computer is to the second".

The gradual achievement of the Millennium Development Goals (MDGs) has also led to an increase in the number of post primary and secondary students in developing countries (World Bank, 2006).This has generated a tremendous demand for higher education, which many countries cannot satisfy by building schools. C.O.L (2005) stressed that developing countries must find alternative methods to conventional education so that people can continue to learn. 
Nowadays, e-Learning offers the solution to some of our problems in education. The term e-Learning came into existence in the late 1990s. But before then, some of its aspects were already taking place. First there was correspondence learning. Then came distance learning. The scope and status of e-Learning is constantly changing due to continual developments in new technology, hardware and software respectively. Since 1998, the number of colleges and Universities offering online courses has increased dramatically. Piskurich (2004) reported that in 1999, U.S corporations spent $\$ 66$ billion on training. About 20 percent of that was expended on e-Learning and about 80 percent on traditional classroom instruction. Stacy (2000) cited in Piskurich (2004) predicted a projected shift to 60 percent e-Learning and 40 percent classroom instruction by 2003. E-Learning models give a clearer picture of its evolution. Engelbrecht (2003) remark that e-Learning models have evolved from classroom replication (models that emphasized the role of the technology in providing content, delivery and electronic services) to models that focus on pedagogical issues such as online instructional design and the creation of online learning communities.

In Cameroon, the Internet has become a tremendous resource for its citizens. E-mail services, Net phones and Websites are currently available in major towns and cities across the country. Though Internet services became operational as early as 1972, it emerged in Cameroon only in the late 1990s. And since then, it has become something of great interest especially among high school and University graduates. "Cyber Cafés" and "call booths" have been cropping up steadily in urban and rural centres. The Cameroonian youth takes particular interest in social media like Facebook and Twitter. Students use Internet for research, scholarships, and pen friends, It is worthy to note that most institutions like Universities, socio-political and business groups have already developed their own Websites. The Cameroon government has made great efforts to respond to the need for quality education and the demands of globalization. Amongst these could be cited, the liberalization of the audio-visual media sector, the abolition of custom charges for imported communication equipment and the introduction of computers and internet facilities in schools, colleges and Universities. A lot of research has been carried out in most countries of the world on the future potentials of ICTs in the development process. To date, however, we know very little about the challenges of e-Learning. It is on this note that this study sought to find out some of the challenges faced by teachers in the implementation of eLearning.

\section{Literature Review}

\subsection{Conceptual Background}

The main concepts that form the basis for the theoretical framework will be discussed in this section. According to C.O.L (2006), e-Learning and online learning are terms that have emerged to describe the application of Information and Communication Technologies (ICTs) to enhance distance education, implement open learning policies, make learning activities more flexible and enable those learning activities to be distributed among many learning venues. E-Learning which is online or Web-based can be used in conjunction with face-to-face teaching. In this case, the term Blended learning is used. Also, where mobile technologies are used, the term mobile learning has become more common. Lumadi and Kibinkiri (2013:792) states that e-Learning is a modern strategy or method of teaching and learning which involves Computer-Based Direct Instruction (CBDI), Asynchronous Experiential Learning (AEL), Asynchronous Collaborative Learning (ACL), Internet Based Problem Solving (IBPS), Online Content Representation (OCR), and Online Learning Environments (OLE).

Also, Noe (2002) points out three important characteristics of e-Learning:

1. E-Learning involves electronic networks that enable information and instruction to be delivered, shared, and updated instantly.

2. E-Learning is delivered to the trainee or learner using computers with Internet technology.

3. It focuses on learning solutions that go beyond traditional training. E-Learning goes beyond training to include the delivery of information and tools that improve performance.

Indeed, e-Learning is a multi-dimensional and an all-encompassing term, which vary depending on the context and the availability of appropriate technologies or Information and Communication Infrastructure (ICI). Therefore, as far as this work is concern, e-Learning refers to the use of electronic applications and processes to learn. For example: computer, Internet, PDAs and mobile phones.

\subsubsection{Institutional Advantages of e-Learning}

E-Learning has become the protagonist for change in education sector. Its approaches and applications, which are supported by pervasive technologies, have brought in great benefits to the whole society. C.O.L (2006) presumes that the 
growth of e-Learning will have a transformative effect on open and distance learning that may be difficult at first, but more profound and positive in the longer term. It further explains that this will help overcome physical distance, solve time or scheduling problems, expand the limited number of places available, accommodate low or dispersed enrolments, make best use of limited number of teachers available and deal with individual differences. This will definitely lead to cost savings.

According to Jelmam (2009:153), e-Learning courses delivered online as opposed to on-campus classes have a multiplicative factor: one e-Learning course well prepared and designed can be delivered in several campuses or Universities in a flexible manner. The problem of inadequate qualified teachers can be overcome in part by computers and other forms of distance education that deliver instruction in a cost-effective manner. In addition, e-Learning can facilitate contact between schools, prepare students for high-skilled employment, deliver staff development programs and provide specialized courses. Terry and Daryl (1996) comment that there is scarcely a modern University that is not significantly involved in distance education. Distance education is distance from the classroom, distance from sitting at the foot of the professor, and distance from the physical campus.

Perkinson (2005:114) postulates that e-Learning facilitates access to international faculty and peers, provides flexible access to materials and other resources, enhance face-to-face sessions, and improve communication between faculty and students and also increased peer learning. Noe (2002:261) holds that e-Learning is accessible at anytime and anyplace. He equally mentioned that training can be delivered faster to geographically dispersed learners and that practice, feedback, objectives, assessment, and other positive features of a learning environment can be built into the program. It can also link learners to other content, experts and peers.

Bates (2001:126) points out that the benefits of an online learning course include: Increased access for part-time students, and for full-time students with timetabling or part-time work conflicts; improved access to out-of-province and international students; improved written communication skills; much increased participation by students in discussion through the on-line discussion forums compared with print-based distance education; greater interaction with the instructors than print-based distance education; by widening the market beyond the province, the course comfortably covered its direct costs from student fees, although it is not clear whether all overhead costs would have been covered as well. Indeed, he argues (Bates, 2001:72) that it is not surprising then that governments in a number of countries are looking at e-Learning as one possible means for making post-secondary education more cost-effective, more learnercentred and more economically relevant.

\subsubsection{Individual Learner Advantages of e-Learning}

Semenov (2005:161) reports that ICT provides opportunities for:

1. Facilitating learning for children who have different learning styles and abilities, including slow learners, the socially disadvantaged, the mentally and physically handicapped, the talented, and those living in remote areas;

2. Making learning more effective, involving more senses in a multimedia context and more connections in a hypermedia context and

3. Providing a broader international context for approaching problems as well as being more sensitive response to local needs.

Long (2004:10) identify seven personal learner advantages:

1. Reduced travel time and costs for learners: E-Learning addresses the problem of lack of time and lack of money. For example, it may be less difficult to go to your computer desk at home or work place than to travel across town or even to another building in your work complex. As a result, you may save time and the expenses associated with travel.

2. Self-paced learning whereby learners can control their schedules.

3. Convenience of any time and any place: Learners are not obligated to meet with an instructor or trainer at a specific time.

4. Opportunity for repeated practice: This advantage depends on specific formats and content. For example computer software, training packages based on CDs provide unlimited opportunity to practice different applications.

5. Ease of review: Like opportunity for repeated practice, depends on the kind of e-Learning you choose.

6. Self - responsibility: E-Learning encourages and requires self-responsibility.

7. Freedom: A highly motivated learner, who is comfortable with the asynchronous mode, can use e-Learning in and autodidactic manner. The learner chooses the topic; determine time, set the criteria for success and so 
forth.

E-Learning has the capacity to foster self - directed learning. Knowles (1975) cited in Piskurich (2004) describes self directed - learning as a process in which the learner with or without the help of others, identifies learning needs, defines learning goals, develops and implement a learning plan and evaluates the learning gained. Beckman and Rathswohl (1999) as well as Somekh and Niki (1997) affirm that information technology has become part of our society: the so-called information society of the late twentieth century. It is a statutory right for students with special educational needs where it can give them access to the curriculum of which they were previously deprived. Consequently, it is necessary that teachers and authorities consider how to use information technology effectively in teaching and learning. Governments in Europe, US and around the world have already recognized the need to review traditional educational practices and how to incorporate new technologies.

\subsection{Theoretical Framework}

E-Learning cuts across learning theories. However this study is underpinned by the socio-cultural approach. According to Crook (2001:19) the cultural view frames intelligent action as something that is mediated. Bottino (2004:558) argued that the adoption of this perspective has implications for the support of learning and the design of resources, such as those associated with educational technology. This is true as technological progress is constantly opening up new opportunities for elaboration, representation and communication. These new functions and opportunities can change the models of practice which have inspired the construction of the technology itself. The cultural approach has challenged behaviourism, cognitivism and constructivism's concerns. According to Crook (2001:22), the vision of behaviourism is evident in the design of early teaching machines which focused on Computer Assisted Instruction (simple drill and practice programmes and tutorial systems). With the coming of modern Information and Communication Technologies, these programs have greatly evolved in design and function. A favourable environment or good conditions for learning to the cultural approach is one in which the learner is granted access to complete versions of what is to be learned rather than starting at a distance, and incrementally moving forward as is the case with behaviourism.

Also, the individualism of cognitive psychology is challenged by the socio-cultural emphasis on the distributed nature of learning and knowing. The interest in tool-mediation naturally leads to accounts of intelligent action that attend to the individual's deployment of tools and technologies, symbol systems, genres of communication (Crook, 2001:23). Therefore, cognition should be seen as something to be analysed as 'distributed' across these resources. It is worthy to note that representations may arise during the course of such intelligent activity. Jonassen (2003:362) affirm that new research is focused on the role of tools for externalizing learners' internal representations. According to him, for students to be able to transfer the skills of solving 'well-structured' and 'ill-structured problems', it is essential that they learn how to represent the problem they are solving in more than one way (Jonassen, 2003:364).

To add, the cultural approach challenged constructivism for frequently reinforcing a conception of knowledge as something to be acquired from autonomous and often solitary investigation. The cultural approach situates learning and knowing in a more social context. It embraces the idea that context shapes how we think and know. On his part, Sheared (1994:36) states that essential to the cultural view is engaging "the students' lived experience within a socio-cultural, political, and historical context". However, in terms of educational technology, the constructivist view of knowledge has had its influence. It has encouraged the development of exploratory spaces. That is computer-based simulations and 'Microworlds' that resource the individual's discovery and reflection. Brown (2002:53) presumes that learners often construct and augment their own understanding of the content socially through conversations. Worthy of note is the fact that the cultural approach conceptualises learning and knowledge as participatory, distributed and socially situated.

Moreover, Crook (2001:25) identifies three aspects of the socio-cultural perspective that address ideal conditions for learning. Each of them has implications for new educational technologies with respect to design. These three aspects are: tool mediation, participatory engagement, and social context. He further stressed that the social context is the most urgent for directing our planning of ICT use in education. First, cultural view of teaching and learning stresses the mediated nature of intelligent action. In this light, it emphasizes the idea of learning with computers rather than learning from computers. Educational technology is now often discussed as augmenting and extending intelligence, rather than imparting it. The cultural approach emphasise re-mediation of intelligent action by new technologies. This contrasts with the behaviourist conventional view of augmentation as being 'amplification' of intellectual capacity. According to the cultural approach, computers do not amplify learning and knowing rather they reorganize how it is exercised.

Second, the cultural view of teaching and learning stresses the importance of learners having a participatory relationship to those domains of practice that they are trying to study. This encourages electronic programs that are more interactive. Participatory learning can be realised through classroom collaboration built around computer-mediated 
communication. Wenger (1998) in Crooks (2001:26) states that such ventures illustrate a route towards greater participatory experience that is based upon creating authentic 'communities of practice'. On his part, Tisdell (2005:256) stressed the "connections between individuals and social structures and notions of intersecting personalities". His view appreciates a culturally relevant and spiritual grounded approach to transformative pedagogy. The goal of this approach is to foster interaction, storytelling on a personal and social level through group inquiry. The teacher's role is that of a collaborator with a relational emphasis on group inquiry and narrative reasoning, which assist the learner in sharing stories of experience and revising new stories in the process.

Third, Crook (2001:28) described 'social' as learning experiences and knowing even when there is no one else around (interpersonal relationship). In this light, the social dimension of learning occurs nevertheless when we are educationally engaged. Crook (2001:28) stressed that there is a great need to recognize the role of 'social' into teaching and learning must especially in higher education. However, some lessons of electronic remediation at this level could be usefully extrapolated to other educational sectors and levels.

Finally, this study is designed to find out potential challenges faced by teachers in the implementation of eLearning.

\subsubsection{Research Question}

What are the potential challenges faced by teachers in the implementation of e-Learning?

\section{Research Methodology}

This study was carried out in Cameroon. The country covers a surface area of 475,440 square kilometres and has an ethnically and linguistically diverse population of about 20 million with about 200 linguistic and ethnic groups (Africa Atlases: Cameroon, 2007:7, Cameroon/World bank Report,2012:32). It is bordered to the south by Equatorial Guinea, Gabon and Congo; on its south-west side, it overlooks the vast Atlantic Ocean; to the west by Nigeria; on its eastern side by the Central African Republic and Chad; and to the north by Lake Chad. Cameroon has two official languages, English and French. The country is sub divided into ten regions (North West Region, South West Region, West Region, Littoral Region, Centre Region, South Region, East Region, Adamawa Region, North Region and Far North Region). Each region is further sub-divided into Divisions and Sub-Divisions.

The target population was made up of final year student-teachers in the different Government Teacher Training institutions in Cameroon. That is third year (3rd year) Student-teachers in teacher education schools in Cameroon. The choice of final year students is first of all because of their experience in school as prospective teachers. These are students that have already learnt basic competencies in teaching and technology given that educational technology is already one of the disciplines taught in all schools from nursery to tertiary education. Secondly, the researcher thought that was the level that could generate data necessary for the study. Purposive sampling, cluster sampling, simple random sampling and systematic random sampling techniques were applied where necessary to obtain the sample. Consequently, a survey of 796 student teachers drawn from eight primary government teacher training colleges and three higher teacher training colleges in Cameroon was carried out. Data were collected using a questionnaire. Descriptive statistics was used to analyze the responses of the student-teachers. Means and standard deviations were calculated using the Statistical Package for Social Sciences (SPSS) version 20.

\section{Findings and Discussions}

This study reveals that there are many impediments faced by teachers in implementing e-Learning. The findings show that the various challenges in implementing e-Learning vary from person to person and from one context to another. When the responses of the respondents were scored and categorised, it was noticed that the majority of the studentteachers indicated that slow Internet lines or access speed constitute a serious challenge to effective e-Learning in Cameroon (Mean = 3.2852). The problem of slow Internet lines is as a result of inadequate bandwidth. Bandwidth refers to information that can travel between computers per second. Inadequate bandwidth makes it difficult for learners to download graphics and photos from some websites and may even make the system inactive. This result is substantial because e-Learning depends on the Internet and a strong bandwidth. The problem of slow Internet lines was compounded by Inadequate Information and Communication Infrastructure with a Mean score of 3.2399. This was followed by insufficient knowledge about e-Learning (learning with ICTs) with a Mean score of 3.1847. Following insufficient knowledge about e-Learning was Recurrent power failure (Mean = 3.1143). Lack of ICT based curriculum 
development programmes (Mean $=3.1055)$. The following table presents a summary of the results.

Description of Items Relating to Challenges faced by teachers in implementing e-Learning

\begin{tabular}{|c|c|c|c|}
\hline Items & $\mathbf{N}$ & Mean & Std. Deviation \\
\hline $\begin{array}{l}\text { Inadequate Information and Communication Infrastructure } \\
\text { high cost of Internet services } \\
\text { lack of qualified electronic instructors } \\
\text { Slow Internet lines or access speed } \\
\text { lack of interest by some students and lecturers } \\
\text { Poor implementation of IT projects in schools } \\
\text { Lack of teacher flexibility and creativity } \\
\text { Ineffective teacher training programme on ICT } \\
\text { Insufficient knowledge about eLearning(learning with ICTs) } \\
\text { Recurrent power failure } \\
\text { Lack of ICT based curriculum development programme } \\
\text { Valid N }\end{array}$ & $\begin{array}{l}796 \\
796 \\
796 \\
796 \\
796 \\
796 \\
796 \\
796 \\
796 \\
796 \\
796 \\
796\end{array}$ & \begin{tabular}{l|}
3.2399 \\
3.1043 \\
3.0352 \\
3.2852 \\
2.9523 \\
3.1256 \\
2.9196 \\
2.9196 \\
3.1847 \\
3.1143 \\
3.1055
\end{tabular} & $\begin{array}{l}1.01136 \\
1.02322 \\
0.94703 \\
0.99954 \\
0.93982 \\
0.90243 \\
0.88229 \\
0.96795 \\
0.88584 \\
0.96908 \\
0.86667\end{array}$ \\
\hline
\end{tabular}

Generally, findings reveal that all the items (Inadequate Information and Communication Infrastructure, high cost of Internet services, lack of qualified electronic instructors, slow Internet lines or access speed, lack of interest by some students and lecturers, poor implementation of IT projects in schools, lack of teacher flexibility and creativity, ineffective teacher training programme on ICT, insufficient knowledge about e-Learning (learning with ICTs), Recurrent power failure, lack of ICT based curriculum development programmes) categorized under challenges faced by teachers in implementing e-Learning were very important to the respondents considering the slight differences in the Means and Standard Deviations. These problems identified, are being compounded by the absence of a clear vision for e-Learning in teacher training schools and lack of political and financial commitment. Although in Cameroon, there is the political will as could be seen in the country's sector strategic plan and the countries 2035 vision, there is no financial commitment.

It is worthy to note that these findings are in line with previous studies in other parts of the world. Mclntosh (2005:3) argues that although e-Learning is enabling higher education to reach out on an unprecedented scale, both to geographical areas and to sections of the population previously unreached, at the same time ICTs give rise to new problems, not least the so-called digital divide. According to him as things stand at present, a new divide, between the "info rich" and the "info poor" is added to the traditional divide between the "haves" and the "have-nots". Hennessy, Ruthven and Brindley (2005:183) interviewed teachers in English schools who have begun to integrate ICT into their practice and found out that they tend to "assimilate" or accept use of ICT into existing practices rather than to "accommodate" in terms of changing their subject content, goals and pedagogy.

Also, Ding, Gu and Zhu (2005:70) identified the following problems of e-Learning relating to learners, teachers, learning resources and education quality.

- Learner isolation: loneliness and lack of self-motivation.

- Inexperience of teachers: Among teaching personnel there is a widespread lack of understanding about eLearning and how to design and conduct ICT-based courses

- Lack of quality resources: There is also a lack of materials suitable for online learning.

- Difficulties of quality assurance: While e-Learning is reaching out to increasingly large masses, it is important to pay attention to the qualitative as well as the quantitative aspect. Some institutions tend to neglect the quality of teaching and learning. How to define the quality of e-Learning is, therefore, a challenge for eLearning institutions. Equally difficult problems are involved in the practical application of quality assurance, especially at a time of rapidly expanding enrolments in e-Learning (Ding, Gu and Zhu, 2005:71)

\section{Recommendations}

Zembylas and Vrasidas (2005:66), postulate that "ICTs in themselves, cannot serve as an end in education but that the demand for critical education involving ICT is pressing as the effects of globalisation are experienced". They further explained that critical education requires students and teachers to become critically literate. According to them critical literacy can be promoted by ensuring: critical emotional literacy. That is knowledge of how ICT work, how they construct meanings, how they serve as a form of cultural and emotional pedagogy or hegemony; collective witnessing. That is learning to become a 'witness' and not simply a 'spectator' and finally collective intelligence. Collective intelligence is a 
'universally distributed intelligence' in which no one knows everything or a continuum developed through collective discussion, negotiation and imagination.

Ding, Gu and Zhu (2005:71) stressed that the aforementioned challenges can best be tackled within a holistic learning system by embracing all phases of life, all sectors and all levels of education. They suggested that the concept of e-Learning should be presented not as a complete alternative to campus-based formal education, but rather as a good modality for adult education and as one constituent in a lifelong learning system. According to them, promoting this concept of e-Learning would do much to remove the misunderstandings about lifelong learning that are common among both learners and teachers. On his part, Towndrow (2005:520) believed that teachers could be helped to appreciate that IT makes it possible for them and their learners to play larger and more significant roles in planning and executing tasks that are centred on, and controlled, by them. Therefore, teachers need to monitor what they do in class and reflect on their actions and how to support learners in their work. He later proposed four interrelated stages through which teachers develop as learning task designers. These include:

1. Adoption: Teachers design and implement teacher centred tasks

2. Adaptation: Teachers start using IT to their advantage but also begin to embrace student-centred and higherorder orientations.

3. Appropriation: Teachers personal attitudes to IT change and they are well on the path towards being confident experts and willing learners in task design.

4. Invention: Teachers are able to design, implement, modify, and evaluate tasks that involve multiple solutions, strategies and perspectives either in advance or during their execution if necessary (Towndrow, 2005:520).

In the same light, Beebe (2003:83) states that "human resources are needed to lay a strong foundation for eLearning". He points out five levels of technology professional development for teachers as follows:

1. Entry: Teachers teach students to use technology;

2. Adoption: Teachers use technology to support traditional instruction;

3. Adaptation: Teachers use technology to enrich the curriculum;

4. Appropriation: Teachers integrate technology in their teaching and use technology for its unique capabilities;

5. Invention: Teachers develop new learning environments that use technology as a flexible tool. Learning becomes collaborative, interactive and customized (Beebe, 2003:83).

Coleman and LaPlace (2002:2) in Beebe (2003:84) points out that, transitioning an organization towards any platform of e-Learning should consider the following:

- Make learning a continuous and measurable process, not a one-time event;

- Make up-to-date information instantly available to all users when and where they need it;

- Training should continuously assess the performance of both the information and all learners;

- Develop employees for greater responsibilities through skill-gap analysis;

- Develop course content or use pre-existing courses;

- Publish content in all the formats needed (online, CD-ROM, and print) for a complete training and development program;

- Seamlessly support 'blended' training- the powerful combination of online and instructor-led courses proven to be the most efficient and effective way to train;

- Easily update and re-use information.

Beebe (2003:84) holds that "readiness factors" for e-Learning at the student level include;

$>$ Greater responsibility on the part of the learner to be self-motivated for online participation and interactivity as well as computer literacy, reading and writing, and online research skills.

> Computer experts are needed to deal with the technical aspects of ICT, the back-end of programs, the database aspects, the networks, the computer hardware, the ones and the zeros. Software developers, network administrators, hardware developers, computer makers, and other highly trained technical personnel are all needed in order for a student to make use of a computer and the Internet for learning.

> Finally leaders with vision and with reformed institutions are key determinants of success in the information age.

Also, on his part, Nagy (2008:32) argues that successful ICT development projects require good practices in their design and implementation practices. According to him, such projects should:

$>$ focus on meeting a need or solving a problem-rather than delivering a technology;

$>$ identify low-cost solutions to the problem;

$>$ be demand-driven not supply-driven, so that the solution is adapted to the problem; 
$>$ take advantage of complementary growth in infrastructure;

$>$ understand the target group and design the project accordingly;

$>$ work actively to include all categories of the target group in the project;

$>$ focus on sustainability from the beginning;

$>$ plan for evaluation of outcome and impact from the beginning;

$>$ include a demonstration and dissemination plan ( Nagy, 2008:32)

Strong evidence indicates that successful e-Learning requires a high commitment and drive as well as acceptance of responsibility to work alone and in collaboration with others. Furthermore, learners who do not have the requisite personality and knowledge level for e-Learning are likely to experience problems. E-Learning requires learners to make their own arrangements to gain hands-on experience including accessing equipment and software, and to make the effort to find support when needed. Brown (2002:59) concludes that the challenge of e-Learning is to find ways to respect the fact that much learning takes place inside the classroom as well as outside the classroom on campus or off-campus.

\section{Concluding Remarks}

In conclusion, results have shown that there are many impediments faced by teachers in the implementation of eLearning. The study has also shown that e-Learning harbours many advantages for institutions and individuals. However, the educational system will not be able to support the incessant growth and penetration of ICTs in education without knowledge of the obstacles or potential challenges to be faced by teachers. Thus, these findings will help governments and institutions of learning to define their own standards for e-Learning based on the context, the availability of Information and Communication Infrastructure and the requisite human resources. To meet the challenges of ICTs, institutions of learning need to work in partnership with telecommunication companies, national and international organisations to integrate ICTs in education. Researchers in the field of education need to help teachers and students develop the ability to make proper use of modern technology by effectively integrating it into the teaching-learning process. E-learning should be considered a good modality for adult education and lifelong learning. ICTs should be utilized as an essential tool for developing a deep understanding of content. Teacher training institutions need to understand that the most important aspects in e-Learning are the employment of appropriate learning theory and paradigms, organization of contents, as well as methods and techniques of delivery.

\section{References}

Africa Atlases (2007) Atlas of Cameroon. Les Editions J. A. Paris-France.

Bates, T. (2001) National strategies for e-learning in post-secondary education and training; Fundamentals of educational planning, (70) UNESCO. IIEP"

Beckman, G. and Rathswohl, E. (1999) Computer Confluence: Exploring Tomorrows Technology. (2nd edition), Addison Wesley Longman, Inc, USA

Beebe, M. A. (2003) Partnerships, Alliances and Networks for e-Learning, In A. Maria, M. A. Beebe, M. K. Koffi, O. Banji, and R. Madanmohan (ed) Africa Dot Edu: IT Opportunities and Higher Education in Africa, Tata McGraw-Hill, New Delhi. 69-89

Bottino, M. R. (2004) The evolution of ICT - based learning environments: which perspectives for the school of the future? British Journal of Educational Technology. 35(5), 553-567

Brown, S. J. (2002) The Social Life of Learning: How can Continuing Education be reconfigured in the Future? Continuing Higher Education Review, (John Seely Brown). 66:50-69

C.O.L (2006) Learning and Living with Technology: The Commonwealth of Learning and the Millennium Development Goals. C.O.L

C.O.L (2006) Commonwealth of Learning Development plan 2006-2009. C.O.L

Cameroon/World bank Report (2012) Governance and Management in the Education Sector. Report No. 67201-CM

C.O.L (2005) Open and Distance Learning for Development. Connections. COL, Vancouver, Canada. June 2005/Vol. 10, Number 2,pp116

C.O.L (2006) Open and Distance Learning for Development. Connections. COL, Vancouver, Canada. June 2006/Vol. 11, Number 2, pp1-16

Crook, C. (2001) The Social Character of Knowing and Learning: implications of cultural psychology for educational technology. Journal of Information Technology for Teacher Education, Loughborough University, United Kingdom, 10(1 \& 2), 19-36

Ding, X., Gu, X., and Zhu, Z. (2005) The Chinese Approach In C. McIntosh (Ed) Perspectives on Distance Education, Lifelong Learning and Distance Higher Education. UNESCO/COL

Engelbrecht, E. (2003) "A look at e-Learning models: Investigating their value for developing an eLearning strategy", Progressio, 25(2):38-47

Hennessy, S., Ruthven, K. and Brindley, S. (2005) Teacher perspectives on integrating ICT in to subject teaching: commitment, constraints, caution and change. Journal of Curriculum Studies 37 (2),

155-192. 
Jelmam, Y. (2009) Online education and Interaction in educational discussion Forums, PanAf, (ERNWACA) March 2010, Vol.2 Issue 1 Jonassen, D. (2003) Using Cognitive Tools to Represent Problems. Journal of Research on Technology in Education, 35(3), 362-37

Long, H. B. (2004) E-Learning: An Introduction, In G. M. Piskurich (ed), Getting the Most from ONLINE LEARNING, (John Wiley and Sons: San Francisco), 7-22

Lumadi, M. W. and Kibinkiri, E. L. (2013) The Role of E-Learning in the Professional in the Professional Development of StudentTeachers in Cameroon: A Discourse in Curriculum. Mediterranean Journal of Social Sciences. MCSER Publishing, Rome-Italy. $791-800$

McIntosh, C. (2005) Perspectives on Distance Education, Lifelong Learning and Distance Higher Education. UNESCO/COL

Nagy, K. H. (2008) Transforming Government and Empowering Communities: The Sri Lankan Experience with e-Development. The World Bank, Washington. DC.

Noe, R. (2002). Employee Training and Development. (2nd edition), McGraw-Hill. New York,

Perkinson, R. (2005) Beyond Secondary Education: The promise of ICT for higher education and lifelong learning, In World Bank (Ed). E-Development: From Excitement to Effectiveness. (The World Bank, Washington), 101-125

Piskurich, G. M. (2004). Getting the Most from ONLINE LEARNING. John Wiley and Sons: San Francisco.

Sheared, V. (1994) "Giving Voice: An Inclusive Model of Instruction—A Womanist Perspective." In E. Hayes and S.A.J. Colin III (eds.), Confronting Racism and Sexism in Adult Education. New Directions for Continuing Education, no. 61. Jossey- Bass: San Francisco

Somekh, B. and Niki, D. (1997) Using Information Technology Effectively in Teaching and Learning. Routledge 11 New Fetter Lane, London.

Terry, T. and Daryl, N. (1996) Opening Education: Policies and Practices from Open and Distance Education. Routledge, New York

Tisdell, E. J. (2005) "Feminism." In L. M. English (ed.), International Encyclopedia of Adult Education. Palgrave: London

Towndrow, P. (2005) Teachers as digital task designers: an agenda for research and professional development, Journal of Curriculum Studies, 37(5), 507-524.

World Bank (2006) Global Issues for Global Citizens: An Introduction to Key Development Challenges. The World Bank, Washington DC.

Zembylas, M. and Vrasidas, C. (2005), Globalization, information and communication technologies, and the prospect of a 'global village': promises of inclusion or electronic colonization? Journal of Curriculum Studies, 37(1), 65-83. 